\title{
Evolution, institutional analysis and path dependency: an administrative-history perspective on fashionable approaches and concepts
}

\author{
Jos C.N. Raadschelders
}

Wir wollen durch Erfahrung nicht sowohl klug (für ein andermal) als weise (für immer) werden. (Jacob Burckhardt, 1860/1945)

\section{Introduction}

The study of social change is important to the social sciences and, as Bottomore (1972: 283) reminded us, has from the beginning been inspired by understanding the 'rapid and violent changes in European societies in the eighteenth and nineteenth centuries'. As an aspect of social change, the development of and changes in government has attracted increasing attention in the 20th century. In this article I explore to what degree administrative history may be enriched by neo-institutional analysis and its notion of path dependency. The interest in social change is both academic as well as practical. Throughout the 19th and 20th centuries scholars have attempted to adequately analyse and explain the nature of the rapid changes they observed in the politics and the society of their times. In whatever manner this has been done, it involves a major intellectual challenge. From an academic point of view the question is: How can we come to full, or at least some, understanding of the impact of time on the present and on the social changes we are surrounded with? Related to this question and from a more pragmatic angle: Do analyses of developments in space and time help us to provide the necessary insights upon which decision makers can make the critical choice between the range of alternatives they are faced with? Both academics and practitioners are in search for what is possible given political choices made in the past and the contemporary socioeconomic constraints.

Three major periods can be distinguished in the attention of the social sciences for the phenomenon of social change. The first period, in the second half of the 19 th century, is one characterized by the search for universal theories. Social evolution was conceptualized as progress. This resulted in general evolutionary theories, encompassing society as a whole. The second period, the 1950 s and $1960 \mathrm{~s}$, is characterized by the more modest search for lawlike generalizations and

Jos C.N. Raadschelders is at the Department of Political Science, University of Oklahoma. CDU: 35.06 .

International Review of Administrative Sciences [0020-8523(199812)64:4]

Copyright (c) 1998 IIAS. SAGE Publications (London, Thousand Oaks, CA and New Delhi), Vol. 64 (1998), 565-582; 006235 
middle-range theory. Social evolution was conceptualized as differentiation. This resulted in institutional theories with respect to specific segments of society (especially the state and political systems). In both the first and second periods the study of social change was predominantly conducted in the fields of political science and sociology. It appears that in the third period, the mid-1980s up to the present, we again have stepped up our efforts to develop middle-range theory. The central approach at the moment can be defined as 'neo-institutional analysis' and path dependency appears to be the key concept. Nowadays both political science and public administration actively study large-scale social changes, such as the consequences of internationalization and globalization and the consequences of European integration for national administrative systems.

The institutional analysis of the 1950s and 1960s as well as current neoinstitutional analysis embraces a comparative-historical approach. Most research in this tradition has been conducted within the social sciences and thus departed from an explicit theoretical-conceptual framework. An excellent recent example of this approach would be Finer's monumental study that opens with an extensive conceptual prologue (Finer, 1997). Gladden's book on the history of government is written in a more traditional chronological fashion with few explicit conceptualizations guiding the organization of his study (1972). While one would think that this is a characteristic of the historian's trade, this factual approach also dominated the studies of legal historians and social scientists (sociology, political science, public administration) who work(ed) in the field of administrative history (for an overview of the literature: Raadschelders, 1998). Administrative history is an interdisciplinary field the output of which could profit from the sharpened analytical focus that institutional analysis at the moment seeks to provide. In this article the notion of path dependency is analysed in its usefulness for administrative history. A few years ago content, meaning and usefulness of administrative history were discussed in this journal (Raadschelders, 1994).

\section{An evolutionary perspective on institutions}

The analysis of (the development of) institutions comes in many guises. Relevant to public administration is the type of institutional analysis as it is pursued within the legal, historical, economic and political science disciplines. Institutional analysis in the fields of social psychology and cultural anthropology is beyond the scope of this article.

In the legal discipline institutions have always been approached as formal arrangements, either as a set of arrangements for public conduct and individual behavior (whether codified or not) or as a set of public and private organizations. The development of law and public organizations was and is the topic of legal history. In the historical discipline, institutions were approached in a manner comparable to the legal discipline with an emphasis on public organizations. Before the Second World War, both the legal and historical disciplines in western countries interpreted 'institutional analysis' as the examination of formal constitutions and organizations. A proper definition of institutions was not provided. 
In the early social sciences evolutionary theory stood at the core of attention. This interest waned for two reasons. First, since the turn of the century scholars have come to believe that the development of human society was neither unilinear (the idea of universal stages of development) nor convergent (the idea that we all move to one end stage). Second, institutional theory has failed to

specify fully the systematic characteristics of evolving societies or institutions, as well as the mechanisms and processes of change through which the transition from one 'stage' to another was effected. (Eisenstadt, 1964a: 375)

The attention shifted to systematic analysis of social systems (social geography). Thus institutional analysis in the 1918-40 period was understood in terms of the analysis of structures, organizations and constitutions and, as such, was heavily influenced by Max Weber (1980).

The critique that Weber's ideas generated from the 1940s onward, especially about bureaucracy, was part of a larger controversy as to whether individual and informal behavior, rather than formal institutions, ought to be the focus of attention in the social sciences. Behaviorism inspired a variety of studies concerning both the private and the public sector. The behavioral approach to public and private institutions was redirected from the mid-1960s on as part of the research effort into the importance of the organizational environment, and the contingency and population ecology schools produced valuable insights. Also, substantial research was conducted regarding the degree of correlation of the various attributes of organizational structure (e.g. the Aston group). In general, the analysis of institutions became dispersed among many different areas of interest and institutional analysis was defined according to the varying needs of those particular interests. Much of the behavioral and organizational research of institutions was structural-functionalist by nature. But the 1950s and 1960s also witnessed increasing interest in historical and comparative analysis (see later), which implied revision and reappraisal of the 19th century evolutionary theory (Eisenstadt, 1964a: 375).

In the last decade Coase's theorem that institutions matter when it is costly to transact, hence that (1) human interaction is constrained and coordinated by the institutions within which they operate and that they themselves have created; and (2) that the cost of human interaction (the transaction costs) ought to be part of any cost-benefit analysis, has become very influential (North, 1990: 11-12), at first, of course, in economics (Davis and North, 1971; North 1990: 12). In the rational choice approach to institutional analysis the transaction costs are emphasized, while in the historical-interpretative tradition the focus is more on social evolution as a path or branching process (Scott and Meyer, 1994: 83; Thelen and Steinmo, 1992: 7, 27). The historical-interpretative tradition of institutional analysis has assumed a more prominent place in the political and administrative sciences since the mid-1980s. This approach is also known as historical diffusionism (or historical institutionalism). 


\section{The nature of institutional analysis}

The analysis of institutions has been pursued in a variety of approaches, depending upon the discipline. As an approach, however, institutional analysis presupposes a theoretical-conceptual point of departure which guides the collection of data. There appears to be a consensus about the analytical distinctions between institution (value) and organization (structure) (Blondel, 1990: 8-9; North, 1990: 4; Uphoff, 1986: 8-9). Uphoff's definition is relevant to public administration:

institutions, whether organizations or not, are complexes of norms and behaviors that persist over time by serving collectively valued purposes. . . Some institutions have an organizational form with roles and structures, whereas others exist as pervasive influences on behavior. (Uphoff, 1986: 9)

Equally relevant, for emphasizing a different aspect, are the definitions of North and E. Ostrom:

Institutions are the rules of game in a society or, more formally, are the humanly devised constraints that shape human interaction. (North, 1990: 3)

the set of rules actually used (the working rules or rules-in-use) by a set of individuals to organize repetitive activities that produce outcomes affecting those individuals and potentially affecting others. (Emphasis in the original; Ostrom, 1992: 19)

Both the study of roles and of rules have attracted much attention in the social sciences. Inherent to these definitions is a dynamic approach to institutions (persistence over time, repetition). Rules and rule configurations appear to be the cornerstone of the administrative science approach since it allows analysis of both abstract institutions such as freedom, equality, governance, etc. as well as of more concrete organizational structures. Olsen emphasizes both roles and rules but he also draws attention to the embedded nature of them:

A 'living' institution, then, is a collection of practices and rules, defining exemplary or appropriate behavior for groups of actors in specific situations. Such practices and rules are embedded in structures of meaning and schemes of interpretation which explain and legitimise practices and rules. (Olsen, 1995: 5)

North explicitly stipulates the importance of distinguishing between institutions and organizations, since he believes that a theory of institutions can only be developed when the analysis of the underlying rules (the institution) is separated from the strategy of the players (the organization) (North, 1990: 5). The difference between these contemporary definitions and those of the 1950s and 1960s is clear. In the 1950s and 1960s scholars such as Eisenstadt (1964b: 235), Parsons (1964: 339) and their many followers analysed the institutionalization of organizations in terms of differentiation. Nowadays institutional analysis is 
occupied with the development of norms, rules, values and the impact of these (developments) on the development of organizations such as government and the state.

Central to institutional analysis is the idea that institutions and organizations are the product of a development over time. An institution and an organization that has been able to meet peoples' (normative and material) expectations over time is accepted ('institutionalizes'). Defining legitimacy as accepted authority, such acceptance of authority can only be the outcome of a development in time. Assuming that (government) institutions in one culture (or country) do not develop independently from other cultures in the same cultural area (e.g. western civilisation), institutional analysis automatically includes a comparative perspective.

Institutional analysis is a rather generic concept that - as a tool for research could suffer from the absence of a clear focus. An institutional analysis that is focused on economic growth or economic performance will use concepts and insights derived from economics. An institutional analysis focused on government and administration (i.e. administrative history) will use concepts and theories from public administration and related disciplines. Whatever the discipline, though, contemporary neo-institutional analysis has one feature in common: the notion of path dependency.

\section{The impact of time as path dependency}

Historians analyse developments in a particular time-space 'through categories of continuity, diversity, and change' (Tholfsen, 1967: 6-7). Institutional analysts seek to unravel continuities, diversities and changes, and attempt to establish the intensity and scope of them. Eisenstadt has already remarked that

reappraisal of an evolutionary perspective is contingent on systematic explanation of the processes of change within a society, the processes of transition from one type of society to another, and especially the extent to which such transition may crystallise into different types or 'stages' that evince some basic characteristics common to different societies. (Eisenstadt, 1964a: 375)

With Tholfsen's three categories in mind we can understand Collier and Collier (1991: 37) when they argue how a constant cause (recurring event) contributes to the presumed stability of the legacy of a major institutional change (they speak of 'critical juncture'), while that constant cause was not the product of the critical juncture. Historians do not necessarily attempt to link the past to the present and certainly their first and foremost concern is not how to solve contemporary problems. To them history is not a magic box and certainly not a manager's toolkit. The need to find solutions in the past for present and future problems, and hence the need to link the past to the present, is more prevalent in the social sciences. And it is not only a link that social scientists look for but also for a predetermined pattern that varies from society to society: 
different societies arrive at the same level of differentiation through different historical paths and through a variety of concrete structural forms. (My emphasis; Eisenstadt, 1964a: 382-3)

The fact that social scientists look for predetermined patterns does not mean that they are not as sensitive to contingency as historians are. The fact that through comparison social scientists unravel differences and similarities in national developments indicates that they are aware of such contingencies. That societies reach comparable levels of differentiation does not mean that the social structure of these societies will actually converge. Eisenstadt was very clear about this when he remarked in the same article:

Not only may different institutional contours and integrative mechanisms develop at each level of differentiation, but each such structure, once institutionalised, creates its own boundary-maintaining mechanisms, its own directions of change, and its potential for further development or for breakdown and regression. (Eisenstadt, 1964a: 381)

The notions of 'different historical paths' and of 'boundary-maintaining mechanisms' has settled in the conceptualizations of many scholars. Thus North recently remarked:

Today's and tomorrow's choices are shaped by the past. And the past can only be made intelligible as a story of institutional evolution. (North, 1990: vii)

The more that the image of 'paths' is rooted in our minds, the more we come to believe that it will actually be possible to 'map' all these paths. Much as 19thcentury evolutionists believed that it would only take time to discover what propelled social change, late 20th-century institutionalists profess to believe that at some point we will 'discover' paths. It is certainly implied in the following quotes:

outcomes during a crucial transition establish distinct trajectories within which ... 'one damn thing follows another'. (David as quoted in Collier and Collier, 1991: 27)

where you can get to depends on where you're coming from, and some destinations you simply cannot get to from here [and so it is important, JR] . . to understand how history smooths out some paths and closes others off. (Putnam, 1993: 179, 181)

This approach to social evolution is conceptualized in the term path dependency (Krasner, 1984: 234; 1988: 67) and captures elegantly (1) the historical notions of continuity, diversity and change; (2) the historians' sensitivity to time and context; and (3) the social scientists' preference for modeling and prediction. Path dependency not only connects the past to the present but highlights the fact that the past limits the range of choices in the present.

The renewed historical perspective in the social sciences started in the 1950s-70s with research in processes of state-making and nation-building includ- 
ing attention to both early states (Claessen and Skalnik, 1970; Eisenstadt, 1958, 1963, 1970; Wittfogel, 1957) as well as western states (Rokkan, 1975; Tilly, 1975). This topic continues to generate interest as the recent studies by Tilly $(1990,1994)$ show. In the face of growing intertwinement between economics and politics, economists and political scientists in the past two decades have come to explore the role of institutions. This renewed interest in political economy has developed along two distinct 'schools' of thought (Hemerijck, 1992: 14-17; Maier, 1987: Ch. 1). The 'economics of politics' school adheres to methodological individualism and applies the tools and methods from the economic discipline. Public choice theory was developed in this context. Individual behavior and individual choice explain action. Among advocates of this approach one can find such renowned economists as Buchanan, Coleman and Schumpeter, as well as administrative and political scientists like Downs, Olson and V. Ostrom. The 'politics of economics' school, on the other hand, emphasizes collective entities as analytical points of departure. Furthermore it embraces the idea that individuals act within institutional arrangements, the present structure and functioning of which is understood only partially, if not without meaning, when not embedded in a historical perspective.

Maier spoke of 'historical political economy analysis', an approach in which description and explanation rather than prescription and prediction dominate (Hemerijck, 1992: 22; Maier, 1987: Ch. 1). The idea that institutional arrangements are determined by particular situations, shaped by both conscious action or agency and path-dependent historical accretion (Hemerijck, 1992: 23), has an immediate bearing on the limitations and possibilities of prescription and prediction. Path dependency also renews the attention for the 'founding moment' of institutions (Hemerijck, 1992: 73). The importance of the time of origin on the development of institutions and organizations has been recognized and analysed before (Meyer and Brown, 1977; Meyer et al., 1985: 131; Stinchcombe, 1965). In the 'liability of newness' hypothesis Stinchcombe (1965) states that new organizations are more likely not to attain their goals than older organizations. This idea can also be found in the population ecology approach that refers to organizational inertia, in the sense that existing organizations are difficult to replace. Path dependency is another way of conceptualizing the tendency that enduring institutions may show signs of institutional rigidity.

Well into this century, the notion of 'development' in much of the political and administrative science literature has been approached in terms of progress which is a 19th-century outlook on the past. It is not only that progress is interpreted in terms of a movement from a lower to a more advanced level of development but it is also conceptualized in terms of convergence. In this view, political and administrative systems are assumed to converge toward one model, for instance that of liberal-capitalist democracy or that of bureaucracy. This type of thinking is suggested by such titles as The Bureaucratization of the World (Jacoby, 1976) and it cannot be denied that something of that nature has happened. However, in their definition of 'critical junctures' as 
a period of significant change, which typically occurs in distinct ways in different countries (or in other units of analysis), and which is hypothesized to produce distinct legacies

(Collier and Collier, 1991: 27) remind us that convergence appears at an abstract level while diversity becomes apparent at the more detailed and empirical level. Convergence is also reflected in many of the stage models through which scholars in various disciplines have tried to come to grips with historical chaos. Such advancement and convergence suggest a historical process that in some remarkable and magical way must be efficient. In a noteworthy article, March and Olsen pointed to this and argued that many social scientists display a contemporary bias:

An efficient historical process ... is one that moves rapidly to a unique solution, conditional on current environmental conditions, thus independent of the historical path. (March and Olsen, 1984: 737)

And, indeed, in a Darwinian evolutionary approach inefficient institutions are weeded out with the mere passing of time. Efficient institutions will survive (North, 1990: 92).

FIGURE 1

The efficient historical process of development

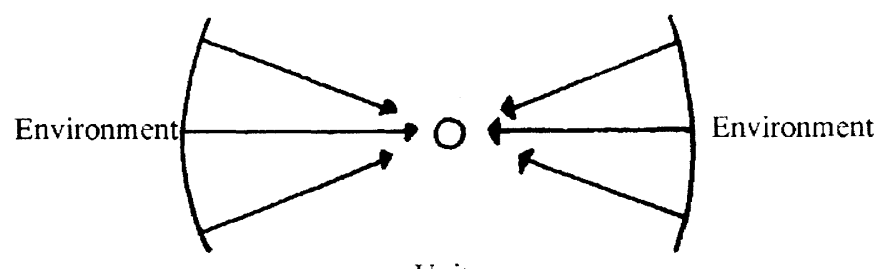

Unit

When is history efficient in this presentation of reality? It is efficient when the past apparently does not inhibit present choices. This is why in Figure 1 a time element is not included. Thus in the 'history-is-efficient' idea 'history' is not synonymous with the 'past', it merely means 'time'; more specifically, something that we perceive as positioned between the 'recent past' and the 'near future'. In that presentation of reality we act on what we see happening ('current environmental conditions'), and that is not quite the same as acting on our experience. In the history-is-efficient approach human beings are portrayed as acting upon present circumstances only. In times of revolutionary change, however, we will seek refuge in our 'experience'. And it is then that the more distant past comes into play. The 'distant past' is both our individual as well as our recorded collective experience. In this light I argue that 'path dependency' is just another way of coming to terms with (i.e. reconceptualizing) the meaning and impact of our 'distant past'. 
In Figure 1, the unit of analysis (object) can be one entity or any number of entities. Acknowledging the impact of the past in terms of diversity and convergence, however, leads to a radically different visual representation that can only be presented in comparative terms. Presenting different paths of development converging toward one outcome, while acknowledging the impact of environmental factors at each time, results in what I would call the simple path-dependent model.

FIGURE 2

The simple path-dependent model of development

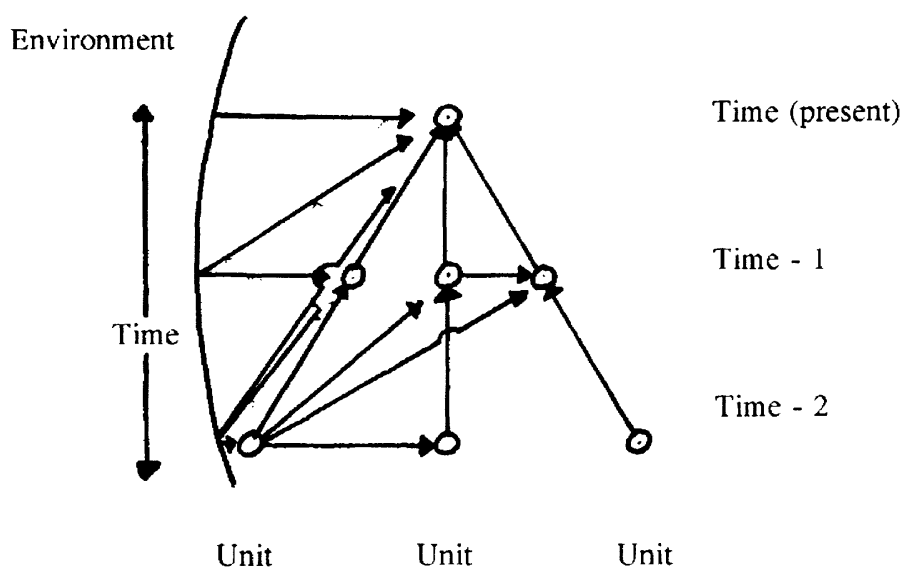

The simple path-dependent model of development (Figure 2) illustrates what I have argued earlier about convergence. Taking, for example, three countries and analysing their development in terms of bureaucratization or democratization often implicitly employs an assumption of convergence. In the simple pathdependent model the center of analysis (e.g. bureaucracy, democracy etc.) is an abstraction illustrated with case-studies. While in such an analysis the diversity between systems of government and the way they developed can be acknowledged, it is the notion of convergence (toward the present time: $T$ ) that dominates. A simple path-dependent analysis, where convergence overarches uniqueness, will not contribute to our understanding. In our current approaches to institutional development, this teleological interpretation of the impact of the past is not sufficient if only because an achieved state of contentment (an equilibrium, the present) cannot be maintained. There is another, more important reason why this interpretation is not sufficient. Assuming that advancement and convergence, hence still an efficient historical process, are indeed the basis of our understanding of the contemporary structure and functioning of state and administrative systems, how then are we to explain the fact that an enormous variety of institutional arrangements can be found once we go beyond the rather general characteristics of political and administrative systems (monarchy, presidential 
system, bureaucracy etc.)? This type of question can, however, only be raised when the primary goal of comparative research is not to establish uniformities in societal development. Seeking uniformity amidst variety meets the naturalistic ideal in the social sciences. It appears that this approach is rapidly becoming obsolete in view of the attempts to look for uniqueness amidst uniformity (Sztompka, 1990: 54-5).

The 'New Institutionalism', as introduced by March and Olsen, addresses this pluralism through acknowledgement of the unique (country-specific) institutional context (see also Lane and Ersson, 1994: 104, 153, 169). While March and Olsen (1984: 737) argue that 'history cannot be guaranteed to be efficient', their discussion of the element of chance in policy-making makes me suggest that, in principle, history is not efficient. That is also suggested by North:

Institutions are not necessarily or even usually created to be socially efficient; rather they, or at least the formal rules, are created to serve the interests of those with the bargaining power to devise new rules. (North, 1990: 16)

And so, March and Olsen's statement that 'not all policy-making processes are independent trial processes' (1984: 745) can be stronger as that, in principle, all policy-making processes are subject to chance. This would be in line with their observation that

this [martingale, JR] property [of whatever, JR] makes the specific path of history important to understanding current historical events. In effect, the chance fluctuations of history change the baselines of the next step of the historical process. Common descriptions of incremental policy processes make them appear to be in the nature of martingales. (March and Olsen, 1984: 745)'

The martingale metaphor is fruitful for understanding the pluralistic manifestation of state and administrative systems. Again quoting from March and Olsen,

In a martingale process all events are forks; the policy paths of two political systems with identical underlying political conditions will be radically different simply because of the way in which (possibly small) perturbations shift the focus of political pressure. (March and Olsen, 1984: 745)

Assuming with March and Olsen (1984: 745), Krasner (1988: 71), and many others that past choices limit future options, the most recent approach to institutional development emphasizes pluralistic complexity both in the past (Time minus 1: $T-1, T-2$, etc.), the present $(T)$ and the future $(T+1, T+2$, etc). This can be visualized in what I would call the complex path-dependent model. In this complex path-dependent model, we look again at our countries - for instance the development of bureaucracy in each of them - and we first try to establish each of the specific paths of development. We use a common theoretical-conceptual framework but are focused on the unique features of each development. Once the developments have been outlined in a satisfactory manner, we need to analyse the extent to which these 'national' paths have diffused to or were influenced 
by developments in other more or less comparable systems or whether these 'national' paths had some common origins. The Collier and Collier (1991) study mentioned earlier is a prime example.

Figure 3 differs from Figure 2 in that, above all, it departs from an empirical point. It departs from concrete units and uses a yardstick (e.g. the ideal type of bureaucracy) to assess the developments in a variety of cases. Also, in Figure 3 convergence is not assumed but is only conceivable. Does this notion of paths get us any closer to what we want? - the ability to adequately conceptualize and analyse our social environment and especially the agents of change. It is interesting to compare the expectations of leading scholars. Thus North (1990: 100):

Path dependence means that history matters. We cannot understand today's choices ... without tracing the incremental evolution of institutions. But we are just beginning the serious task of exploring the implications of path dependence.

Eisenstadt (1964b: 247) had argued along the same lines when concluding that all we needed was 'a full explication of systematic sociological concepts [to] provide a fruitful initial step for the analysis of change'. A recent critical note about this approach to the urge for unravelling societal development through rigid conceptualization was phrased by Albrow:

FIGURE 3

The complex path-dependent model of development (arrows indicate influence of environment and/or other unit)

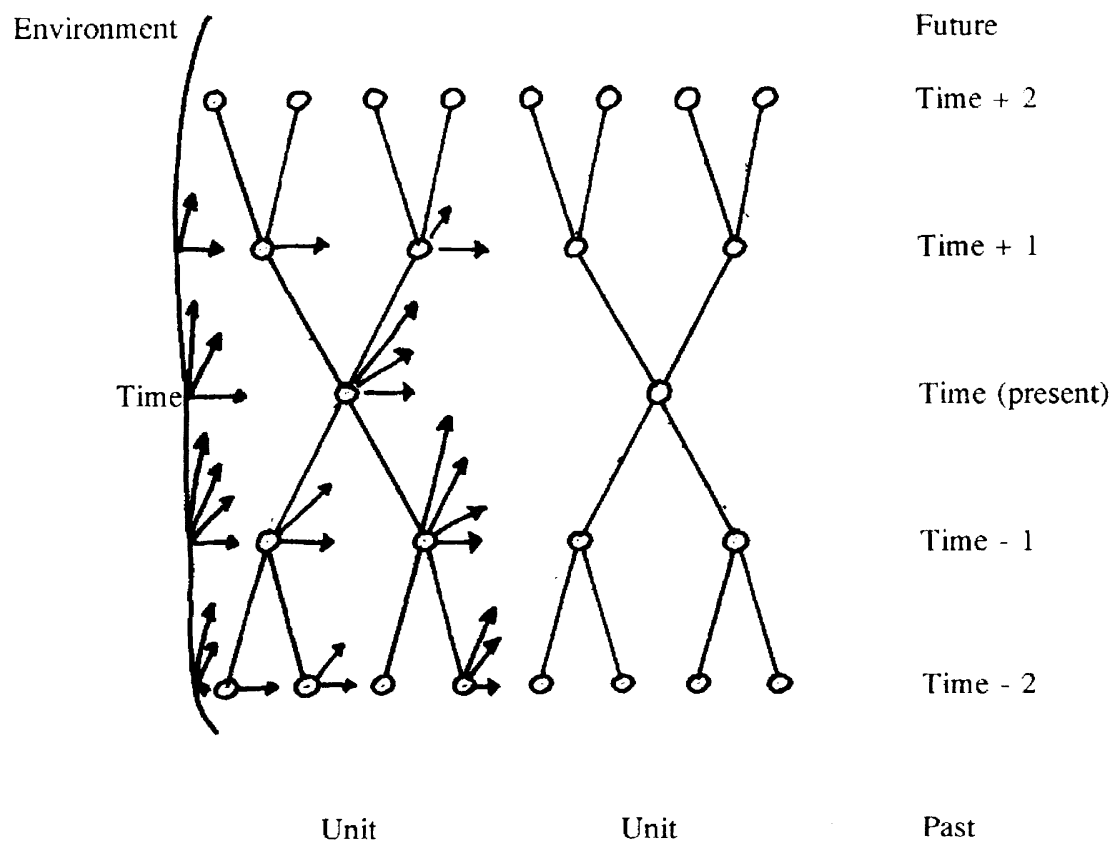


The social sciences have responded to the demand for control of nature and society through providing clarity of concepts, precise data and testable propositions. But that clarity and precision is often highly context and time bound. (My emphasis; Albrow, 1996: 86)

But to John Stuart Mill and Edward E. Freeman the development of a method of comparison would one day lead to discovering the laws of society similar to Newton's laws of thermodynamics (Richter, 1968/69: 134). Indeed, Freeman believed, in Comparative Politics that the comparative method was the greatest intellectual achievement of his time for it held the promise of discovering universal laws through global and longitudinal comparisons (see Lijphart, 1971: 686-7).

As, however, Freeman's contemporary Galton pointed out, lawlike generalizations can only be based on the study of the development of (something) in several cases in a variety of settings occurring independently of other comparable developments elsewhere. If this condition is met, one can use functionalstructuralist theory and claim the results to be universal. If, however, there is even the slightest chance that the development in one case may have been influenced by a comparable development elsewhere, or that the developments in two or more cases have a common root, than we cannot but withdraw into historicaldiffusionist theories (Naroll, 1970; Scheuch, 1990; Sztompka, 1990). Table 1 is the visual presentation of such a historical-diffusionist approach.

Freeman's optimism gave way to realism in the 20th century. But has anything changed since, say, Eisenstadt, or even Freeman? Path dependency as a concept seems to fit our contemporary modest expectations. And yet, there is one element common in the ideas of Freeman, Eisenstadt and North that ought to make us suspicious of our cognitive achievements. Eisenstadt hinted at those limitations when he warned us that

we must discard the assumption ... that the conditions giving rise to structural differentiation, and to structural sensitivity to a greater range of problems, also create the capacity to solve those problems or determine the nature of such solutions. (My emphasis; Eisenstadt, 1964b: 384)

We have to be cautious with promising a problem-solving capacity or even with predicting the emergence of new critical junctures (Collier and Collier, 1991: 773). Not only to prevent disappointment but because the past presented in terms of paths is at best testimony to a reconstructed logic that is bound by context and time. It is only by virtue of retrospect that we are aware of stages or paths of development. 'Path dependency' refers to a string of related events: causality in retrospect. The concept does not come even close to pinpointing $a$ mechanism or the mechanisms that propel social change. The 19th-century stage models may now seem 'too much', but is that what motivated its authors all that much different from the 20th-century hope for consensus about concepts and paths? Whatever paths we have identified, they do not provide us with a hands-on 
solution to the near future. All available path theories (for instance Moore on democracy (1966); Tilly on state-making (1990); Greenfeld (1992) on nationalism) are testimony to the power of reconstructed logic. They represent an attempt, nothing more, nothing less, at understanding the present through the past.

This being so we have not come that much further than the 19th-century evolutionists. Whether conceptualized as progress, differentiation or path, we still tend to view time as something from which we should be able to derive guidelines/lessons. With respect to 'paths', knowing where we came from will not give us much to go on. Do we really expect that identification of paths will help us to identify what options are open to us? Both stage models and path-dependent models are not adequate conceptualizations for guidance. It is, indeed, already a major accomplishment if they can help us to understand the present.

There is another objection to the notion of path dependency. It assumes that we have no other options but those that have been dictated by choices in the past. To illustrate this point, North discusses the path-dependent nature of technology development: once a technology is developed along a particular path, the increasing returns will prevent us from pursuing alternative paths and technologies. Indeed, it is possible that given the initial investments unproductive paths may persist (North, 1990: 76, 99) as martingales. I suppose we can argue that it does not really matter whether there could have been an alternative path. History does not have much use for what-if analysis! Having said that, can we assume that for our understanding of the development of political and administrative institutions and organizations, the technology development as described by North provides a useful analogy? I do not think so, since we cannot possible calculate the 'returns' of particular institutional arrangements, and we certainly are not able to calculate the benefits of a particular change in institutional arrangements. I assume that people in the face of environmental change will fall back on their own experience and/or look around for comparable situations. In that sense, path dependency is not only an analytical tool, but a conservative one at that. It departs from the assumption that seeking security and stability is basic to human nature.

Can we analyse (r)evolutionary changes in a path-dependent framework? In retrospect we can reconstruct paths to and from the Papal Revolutions (Berman, 1983), paths to and from the Reformation, and paths to and from the Atlantic Revolutions. We can also reconstruct paths toward democracy, paths toward nationalism and paths toward contemporary bureaucracy. Since these (r)evolutionary changes have their origins in a distant time, we are able to stand back and reconstruct what happened. Events long past can be evaluated in terms of their current impact and meaning. Thus the Convention during which the American Constitution was written, back in 1787, can now be appreciated for demonstrating "for ever the quality of "law-boundedness" in Western European governments' (Finer, 1997: 1485). But were the authors, such as Hamilton and Madison, conscious of the magnitude of their endeavor? In the words of Spicer and Terry (1993: 240) 'Historical figures are said to have known and understood precisely the motives and intentions governing their actions as well as the future 
consequences of such action'. Or in the words of Finer (1997: 1495): 'In reality these founders were floundering in a mass of uncertainties and had hopes but no knowledge at all of how their handiwork would fare'. And what with recent events of major proportion? No one in the early 1980s could have predicted the major changes which happened in Eastern Europe from 1989 on. The creation of Solidarnosc in 1981 was significant, but the impact of that action did not become clear until some 10 years later. What people could have expected in 1981 is one of at least four outcomes: suppression, routinization (co-opting Solidarity in the existing system without threatening the system), adaptation (mutual) and revolution (Heirich, 1964: 390). Back in 1981 many predicted merely a repeat of the 1968 Prague Spring. And that expectation was path-dependent! Against all odds Walesa persisted but was that because he knew that nothing less than system change would be the path-dependent outcome of his actions or because he hoped for and had blind faith in a break from the path since 1948? In retrospect, the Polish were lucky. Their success depended on many factors outside their control. And even if one knows which path one walks, one cannot possibly know what impact external environmental conditions have. Paths alternative to the 'national' experience may be presented and successfully implemented.

Does all this mean that we have exposed path dependency as yet another fashion? The answer is affirmative when we would emphasize the problemsolving capabilities of path dependency. But the past is not a tool box, and so path dependency is limited to understanding the present. It is said that every generation writes its own history. They not only add to history by their own actions, they also reinterpret, revisit, revision and challenge the 'knowledge' that generations before them generated about the past. Pursuing that logic, I conclude that the paths which we now perceive as tools that we can wield in our problemsolving drive, in time will turn out to be red herrings. Whatever happened to the notion that 'understanding' is a basis upon which we can operate in the present? Paths provide us with understanding and that ought to be enough justification for their use.

\section{Institutional analysis for administrative science}

Institutional analysis has been adopted in public administration following the inspired footsteps of economists and political scientists. While economists provide insights to the distribution of scarcity (and abundance?), and while political scientists offer insights to the distribution of values and of power, public administration is concerned with how to organize such distribution within the existing legal, social, economic and political framework. The question of how to organize is not merely one of structure (organization, procedures, legal framework) but certainly also one of culture (functioning, habits, social-economic context) and thus of institutions. We organize and function in accordance with formal (codified) and informal (customary) rules that have developed over time and, by virtue of their 'age', are considered legitimate.

The path-dependency concept provides the necessary dynamic angle to an 
otherwise static analysis of institutions. In continental Europe, the static analysis is rooted in the legal-administrative origins of administrative science. In the USA, the static approach to institutions betrays a bias in favor of current problems (and problem-solving capacity) as well as a bias in favor of a quantitative statistical approach (emulating the natural sciences). It appears that the natural science approach of the social sciences based on causality and correlation is slowly but inexorably being replaced by a human-oriented approach based on interpretation and perception.

For two reasons perception is intimately connected to path. First, what we perceive to be paths is determined by the space-time in which we have matured. As specialists in perception we know that, while it is impossible to disengage ourselves from our own space-time, we can look at the perception contemporaries had about governance as it was laid down in rules and acted upon in a particular distant or recent past. For the distant past, we cannot but rely on recorded sources (legislation, ordinances, diaries, early statistics, autobiographies, organizational almanacs, etc.), while for the more recent past we can also use 'oral' sources (through interviews, questionnaires, etc.). Attention for rules, formal and informal, on how to organize is appropriate for administrative science but is not yet a framework for institutional analysis. Second, since our perception of what happens elsewhere guides our choice for or against the adoption of certain (foreign) practices and reforms.

Institutional analysts seek continuities, diversities and changes, and attempt to establish the intensity and scope of them. Again, Eisenstadt (1964a: 375) has already remarked that

reappraisal of an evolutionary perspective is contingent on systematic explanation of the processes of change within a society, the processes of transition from one type of society to another, and especially the extent to which such transition may crystallize into different types or 'stages' that evince some basic characteristics common to different societies.

\section{Concluding remarks}

Institutional analysis as approach and path dependency as concept constitute a mild break with earlier approaches of research into ' . . the development of ...'. These changes have been discussed in this article and are summarized in Table 1.

This table does not embrace the idea of 'progress', as will have been clear throughout this article, it merely summarizes a development. What was not evident in the 19th-century search for social laws through comparisons, nor in the mid-20th-century (political science) search for lawlike generalizations via elaborate categorizations and conceptualizations, is glaringly clear in the late 20th-century neo-institutional analysis that searches for (predicting) paths: social science is strong in identifying stages and patterns of developments but it totally lacks an identification of mechanisms that propel social change. Maybe we cannot strive for that and should settle for the more modest construction of stages and patterns. 
TABLE 1

Development of approaches to social change

\begin{tabular}{|c|c|c|c|}
\hline & 19th century & Mid-20th century & Late 20 th century \\
\hline Goal & Grand theory & Middle-range theory & Middle-range theory \\
\hline Key concept & Progress & Differentiation & Path dependence \\
\hline $\begin{array}{l}\text { Interpretation of } \\
\text { progress }\end{array}$ & Improvement & Enlightenment & Enlightenment \\
\hline $\begin{array}{l}\text { Interpretation of } \\
\text { history }\end{array}$ & $\begin{array}{l}\text { Convergence \& } \\
\text { unilinearity }\end{array}$ & $\begin{array}{l}\text { Convergence \& } \\
\text { pluriformity }\end{array}$ & $\begin{array}{l}\text { Uniqueness \& } \\
\text { pluriformity }\end{array}$ \\
\hline Types of analyses & $\begin{array}{l}\text { Evolutionary } \\
\text { analysis }\end{array}$ & $\begin{array}{l}\text { Institutional } \\
\text { analysis }\end{array}$ & $\begin{array}{l}\text { Neo-institutional } \\
\text { analysis }\end{array}$ \\
\hline Conceptualization & Stages & Typologies & Paths \\
\hline What we need $=$ & Comparisons & Concepts & Mechanisms \\
\hline
\end{tabular}

If path dependency represents an attempt to re-introduce a notion of causality in the social sciences, than it should be abandoned quickly. For only then we have really shaken off the 19th-century inheritance. 'Progress' in the 19th century was synonymous with 'improvement'; while in the 18th it was, and upon the eve of the 21 st century can again become, synonymous to 'enlightenment'. I do not see much use for the ambitious approach of path dependency that seeks to outline boundaries upon the power to predict but embrace the 'lean' concept of reconstructing past developments via the construction and analysis of stages and patterns.

\section{Notes}

The author is grateful for the extensive and pointed comments of anonymous reviewers, as well as for the comments of Professor Kenneth Kernaghan.

1. A martingale is inter alia defined as 'any system of trying to make up one's losses in previous bets by doubling or otherwise increasing the amount bet' (Webster's New Twentieth Century Dictionary (New York: Prentice Hall, 1979) p. 1105).

\section{References}

Albrow, Martin (1996) The Global Age: State and Society Beyond Modernity. Cambridge: Polity Press.

Berman, Harold J. (1983) Law and Revolution: The Formation of the Western Legal Tradition. Cambridge, MA/London: Harvard University Press.

Blondel, Jean (1990) Comparative Government: An Introduction. New York: Philip Allen. Bottomore, T.B. (1972) Sociology: A Guide to Problems and Literature. New York: Vintage Books.

Buckhardt, Jacob (1860/1945) The Civilization of the Renaissance in Italy. English trans. (1945). London.

Claesen, H.J.M. and Skalnik, P. (eds) (1970) The Early State. The Hague/Paris/New York: Mouton.

Collier, Ruth Berins and Collier, David (1991) Shaping the Political Arena: Critical Junctures, the Labor Movement, and Regime Dynamics in Latin America. Princeton, NJ: Princeton University Press. 
Davis, Lance E. and North, Douglass C. (1971) Institutional Change and American Economic Growth. London/New York: Cambridge University Press.

Eisenstadt, S.N. (1958) The Comparative Analysis of Historical Political Systems. New York: Committee on Comparative Politics of the Social Science Research Council.

Eisenstadt, S.N. (1963) The Political Systems of Empires: The Rise and Fall of the Historical Bureaucratic Societies. New York: Free Press.

Eisenstadt, S.N. (1964a) 'Social Change, Differentiation, and Evolution', American Sociological Review 29(3): 375-86.

Eisenstadt, S.N. (1964b) 'Institutionalization and Change', American Sociological Review 29(2): 235-47.

Eisenstadt, S.N. (1970) 'Problems of Emerging Bureaucracies in Developing Areas and New States', in Henry A. Lansberger (ed.) Comparative Perspectives on Formal Organizations, pp. 215-30. Boston, MA: Little, Brown.

Finer, S.E. (1997) The History of Government. Oxford: Oxford University Press.

Gladden, E.N. (1972) A History of Public Administration, 2 vols. London: Frank Cass.

Greenfeld, Liah (1992) Nationalism: Five Roads to Modernity. Cambridge, MA/London: Harvard University Press.

Heirich, Max (1964) 'The Use of Time in the Study of Social Change', American Sociological Review 29(3): 386-97.

Hemerijck, Anton (1992) 'The Historical Contingencies of Dutch Corporatism', PhD thesis, University of Oxford.

Jacoby, Henry (1976) The Bureaucratization of the World. Berkeley: University of California Press.

Krasner, Stephen D. (1984) 'Approaches to the State: Alternative Conceptions and Historical Dynamics', Comparative Politics 16(2): 223-46.

Krasner, Stephen D. (1988), 'Sovereignty: An Institutional Perspective', Comparative Political Studies 21(1): 66-94.

Lane, Jan-Erik and Ersson, Svante O. (1994) Comparative Politics: An Introduction and New Approach. Cambridge: Polity Press.

Lijphart, Arent (1971) 'Comparative Politics and the Comparative Method', American Political Science Review 65(2): 682-93.

Maier, Charles S. (1987) In Search of Stability: Explorations in Historical Political Economy. Cambridge: Cambridge University Press.

March, James G. and Olsen, Johan P. (1984) 'The New Institutionalism: Organizational Factors in Political Life', American Political Science Review 78(3): 734-49.

Meyer, Marshall W. and Craig Brown, M. (1977) 'The Process of Bureaucratization', American Journal of Sociology 83(2): 364-85.

Meyer, Marshall W., Stevenson, W. and Webster, S. (1985) Limits to Bureaucratic Growth. New York/Berlin: Walter de Gruyter.

Moore, Barrington Jr, (1966) Social Origins of Dictatorship and Democracy: Lord and Peasant in the Making of the Modern World. Boston, MA: Beacon Press.

Naroll, Raoul (1970) 'Galton's Problem', in Raoul Naroll and Ronald Cohen (eds) A Handbook of Method in Cultural Anthropology, pp. 974-89. New York: Natural History Press.

North, Douglass C. (1990) Institutions, Institutional Change and Economic Performance. Cambridge: Cambridge University Press.

Olsen, Johan P. (1995) 'European Challenges of the Nation State', paper for the SOG conference on New Challenges of the State in Comparative Perspective, Seoul National University, 24-26 October.

Ostrom, Elinor (1992) Crafting Institutions for Self-governing Irrigation Systems. San Francisco, CA: ICS Press.

Parsons, Talcott (1964) 'Evolutionary Universals in Society', American Sociological 
Review 29(3): 339-57.

Putnam, Robert D. (1993) Making Democracy Work: Civic Traditions in Modern Italy. Princeton, NJ: Princeton University Press.

Raadschelders, Jos C.N. (1994) 'Administrative History: Contents, Meaning, and Usefulness', International Review of Administrative Sciences 60(1): 117-29.

Raadschelders, Jos C.N. (1998) Handbook of Administrative History. New Brunswick, NJ: Transaction.

Richter, Melvin (1968/69) 'Comparative Political Analysis in Montesquieu and Tocqueville', Comparative Politics 1(2): 129-60.

Rokkan, Stein (1975) 'Dimensions of State Formation and Nation-building: A Possible Paradigm for Research on Variation within Europe', in Charles Tilly (ed.) The Formation of National States in Western Europe, pp. 562-600. Princeton, NJ: Princeton University Press.

Scheuch, Erwin K. (1990) 'The Development of Comparative Research: Towards Causal Explanations', in E. Öyen (ed.) Comparative Methodology: Theory and Practice in International Social Research, pp. 19-37. London: Sage.

Scott, Richard W. and Meyer, John W. and associates (1994) Institutional Environments and Organizations: Structural Complexity and Individualism. Thousand Oaks: Sage.

Spicer, Michael W. and Terry, Larry D. (1993) 'Legitimacy, History and Logic: Public Administration and the Constitution', Public Administration Review 53(3): 239-46.

Stinchcombe, Arthur L. (1965) 'Social Structure and Organizations', in James G. March (ed.) Handbook of Organizations, pp. 142-93. Chicago, IL: Rand McNally.

Sztompka, P. (1990) 'Conceptual Frameworks in Comparative Inquiry: Divergent or Convergent?', in M. Albrow and E. King (eds) Globalization, Knowledge, and Society: Readings from International Sociology, pp. 47-58. London: Sage.

Thelen, Kathleen and Steinmo, Sven (1992) 'Historical Institutionalism in Comparative Politics', in Sven Steinmo, Kathleen Thelen and Frank Longstreth (eds) Structuring Politics: Historical Institutionalism in Comparative Analysis, pp. 1-32. Cambridge: Cambridge University Press.

Tholfsen, T.R. (1967) Historical Thinking: An Introduction. New York: Harper \& Row.

Tilly, Charles (ed.) (1975) The Formation of National States in Western Europe. Princeton, NJ: Princeton University Press.

Tilly, Charles (1990) Coercion, Capital, and European States, AD 990-1990. Oxford/Cambridge, MA: Basil Blackwell.

Tilly, Charles (1994) 'Entanglements of European Cities and States', in Charles Tilly and Wim P. Blockmans (eds) Cities and the Rise of States in Europe, A.D. 1000 to 1800, pp. 1-27. Boulder, CO/San Francisco, CA/Oxford: Westview Press.

Uphoff, Norman (1986) Local Institutional Development: An Analytical Sourcebook with Cases. West Hartford, CT: Kumarian Press.

Weber, Max (1980) Wirtschaft und Gesellschaft. Tübingen: J.C.B. Mohr.

Wittfogel, Karl A. (1957) Oriental Despotism - A Comparative Study of Total Power. New Haven, CT: Yale University Press. 